\title{
Six new species of Dasyhelea (Insecta, Diptera, Ceratopogonidae) from Patagonia
}

\author{
Florentina Díaz, Gustavo R. Spinelli \& Maria M. Ronderos
}

División Entomología, Museo de La Plata, Paseo del Bosque s/n, 1900 La Plata, Argentina. (mfdiaz@fcnym.unlp.edu.ar; spinelli@fcnym.unlp.edu.ar; ronderos@fcnym.unlp.edu.ar)

\begin{abstract}
Six new species of Dasyhelea Kieffer, 1911 from Argentinean and Chilean Patagonia are described and illustrated based on adults. Five of these species do not belong to any of the recognized groups found in the Americas. The remaining one, Dasyhelea pabloi sp. nov. is a typical member of the leptobranchia group and is the first record of a species from this group found in the Neotropical region.
\end{abstract}

KEYWORDS. Neotropical region, taxonomy, leptobranchia group.

RESUMO. Seis especies nuevas de Dasyhelea (Insecta, Diptera, Ceratopogonidae) de la Patagonia. Se describen e ilustran seis especies nuevas de Dasyhelea Kieffer, 1911 de la Patagonia argentina y chilena. Cinco de estas especies no pertenecen a ninguno de los grupos reconocidos para América. La especie restante, Dasyhelea pabloi sp. nov. es un miembro típico del grupo leptobranchia, lo que representa el primer registro en la Región Neotropical de una especie perteneciente a este grupo.

PALABRAS CLAVE. Región Neotropical, taxonomía, grupo leptobranchia.

Dasyhelea Kieffer, 1911 is a large and complex genus of Ceratopogonidae with diverse morphology and biology, occurring worldwide in a variety of habitats (WAUGH \& WIRTH, 1976).

Taxonomically, the recognition of subgenera and/ or species groups is still incipient and generally have been applied sporadically only to various regional fauna. With regard to the Nearctic region, WAUGH \& WIRTH (1976) reviewed the cincta, grisea, leptobranchia and mutabilis groups, BORKENT \& FORSTER (1986) the fasciigera group and GROGAN \& WIENERS (2006) the brevicornis group.

Borkent (2009) mentioned 58 species for the Neotropics. Of these, 40 species belong to the groups recognized for the Nearctic region except the leptobranchia group, and the remaining 18 could not be grouped mainly due to their very incomplete original descriptions and, as it is the case of the species described by KIEFFER (1917), the inexistence of types.

During the past 20 years several collecting trips to many localities in Argentinean and Chilean Patagonia were undertaken, resulting in a large collection of adults of the genus Dasyhelea, deposited in the Museo de La Plata, Argentina. The taxonomic revison of this collection reveals the presence of 28 species, three of the cincta group (reviewed by Díaz et al., 2009), seven of the patagonica group, recognized during this study (DíAz et al., 2010), 12 of the mutabilis group (unpublished data), one of the leptobranchia group and five that do not fit in any of the already recognized groups for the Americas. The purpose of this paper is to describe and illustrate the lastly mentioned six species.

\section{MATERIAL AND METHODS}

All specimens were slide mounted in Canada balsam, examined, measured and drawn using a binocular compound microscope with attached camera lucida. Terms for structures of adults follow McAlpiNe et al. (1981). Terms for wing veins follow the system of McAlPine et al. (1981), with modifications proposed by SzADZIEWSKI (1996).

The holotypes of the new species are deposited in the collection of the División Entomología, Museo de La Plata, Argentina (MLP). When available, paratypes will be deposited, as noted, in the Natural History Museum, London (NHM). During this investigation we studied the specimens collected by Anthony J. Downes in southern Chile, which are housed in the Canadian National Collection of Insects (CNCI). When the specimens belong to the later collection, it is written the collector nomenclature after the locality (e.g., JAD 1702/1).

\section{Dasyhelea ferreyrai Díaz \& Spinelli sp. nov. (Figs 1-12)}

Diagnosis. The only species of Dasyhelea from Patagonia distinguished by the following combination of characters: tip of posteromedian projection of male sternite 9 rounded, parameres symmetrical, its basal arms not fused to bristle-like posteromedian projection, aedeagus with forceps-like posterolateral projections. Female subgenital plate small and subtriangular, spermatheca rounded with long, oblique neck.

Male. Similar to female with the usual sexual differences. Flagellum (Fig. 1). Palpus (Fig. 2) with third segment bearing scattered sensilla (not visible in the holotype); PR 4.54 (4.22-5.00, $\mathrm{n}=10$ ). Scutellum with 7-9 long setae, 6-8 shorter ones. Wing (Fig. 3) length 1.07 $(1.00-1.20, \mathrm{n}=10) \mathrm{mm}$, width $0.34(0.28-0.40, \mathrm{n}=10) \mathrm{mm}, \mathrm{CR}$ $0.52(0.50-0.54, \mathrm{n}=10)$. Genitalia (Fig. 4): tergite 9 slightly tapering distally, not reaching level of apex of gonocoxite, apex slightly concave, apicolateral process short, with apical seta; cercus small, with 2-3 setae; sternite 9 (Fig. 5) 0.7 times longer than greatest width, lateromedial angles of posteromedian projection blunt, mesal portion of projection rounded, produced body of aedeagus by short distance. Gonocoxite stout, 1.9 times longer than greatest 
width, with blunt anteromedian process directed mesad; gonostylus as long as gonocoxite, slightly curved, tip pointed. Parameres (Fig. 6) symmetrical, well sclerotized; stout apodemes, basal arms straight, not fused to posteromedian projection, later bristly-like. Aedeagus 0.7 times longer than greatest width; body well sclerotized, anterior margin slightly excavated, basal arms short directed anterolaterad, distal portion truncate; posterolateral arms curved, well sclerotized anteriorly, tip forceps-like.
Female. Head dark brown. Eyes contiguous by width of 4-5 ommatidia. Antenna with flagellum (Fig. 7) pale brown; AR 0.86 (0.80-0.91, n=5). Clypeus (Fig. 8) with 4-5 pairs of setae. Palpus (Fig. 9) pale brown, third segment with 5-6 capitate sensillae on anterior inner surface; PR $3.91(3.88-4.00, \mathrm{n}=4)$.

Thorax. Scutum dark brown; scutellum paler, with 6-8 long setae, 8-10 shorter ones. Legs dark brown, tarsi slightly paler; hind tibial comb with 6 spines; prothoracic

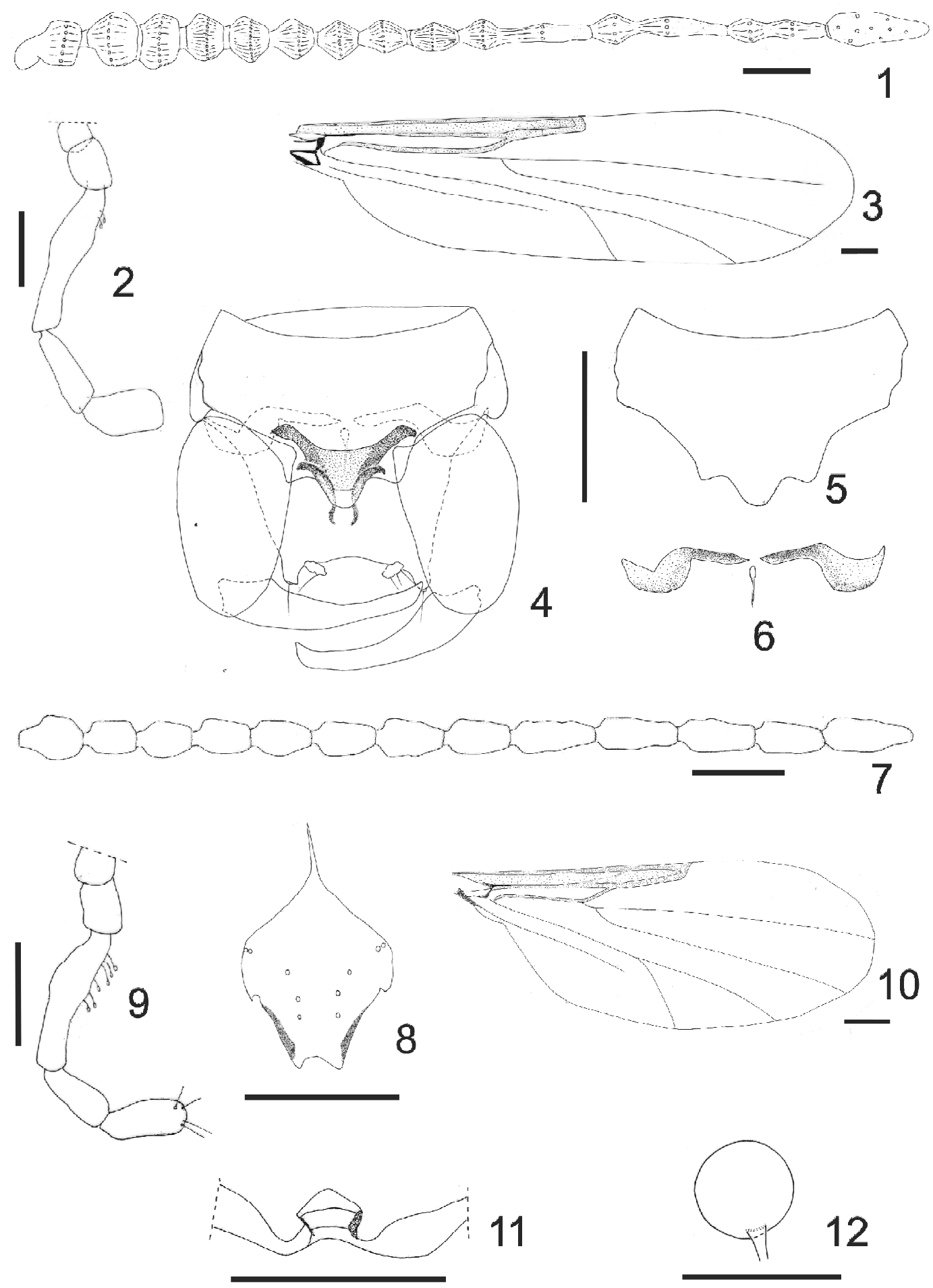

Figures 1-12. Dasyhelea ferreyrai Díaz \& Spinelli sp. nov. 1-6, male: 1, flagellum; 2, palpus; 3, wing; 4, genitalia; 5, sternite 9; 6, parameres; 7-12, female: 7, flagellum; 8 , clypeus; 9, palpus; 10, wing; 11, subgenital plate; 12 , spermathecae. Scale bars: $0.05 \mathrm{~mm}$. 
TR 1.91 (1.63-2.10, $\mathrm{n}=5)$, mesothoracic TR 1.81 (1.58-1.91, $\mathrm{n}=5)$, metathoracic TR $1.66(1.45-1.85, \mathrm{n}=5)$. Wing (Fig. 10) length $0.85(0.82-0.88, \mathrm{n}=5) \mathrm{mm}$, width $0.39(0.34-0.42$, $\mathrm{n}=5) \mathrm{mm}, \mathrm{CR} 0.54(0.50-0.59, \mathrm{n}=5)$; membrane hyaline, densely covered with macrotrichiae; cubital fork at same level of anterior portion of second radial cell. Halter brown, knob base whitish.

Abdomen. Dark brown. Subgenital plate (Fig. 11) subtriangular, small, anterior blunt tip, lateral margins slightly concave, posterior margin slightly excavated. Spermatheca rounded (Fig. 12) well sclerotized, with long, oblique, slender neck, measuring 0.032 by $0.032 \mathrm{~mm}$, neck $0.012 \mathrm{~mm}$.

Distribution. Argentina (Salta, La Rioja, Córdoba and Río Negro provinces).

Type material. Holotype $\sigma^{7}$, ARGENTINA, La Rioja: RN 40 , río Miranda $\left(29^{\circ} 20^{\prime} 50.4^{\prime} \mathrm{S}, 67^{\circ} 42\right.$ ' 12.8 ' W, $\left.1590 \mathrm{~m}\right)$, 17.XI.2007, G. Spinelli col., at ligth. Allotype ${ }^{\text {, Salta: Cayafate, }}$ 02.XII.1986, G. Spinelli col. Paratypes, $180^{7}, 5 \circ$ as follows: $100^{7}$, same data as holotype; $20^{\circ}$, same data holotype except, 17 , 18.XI.2007, G. Spinelli col.; $2 \sigma^{2}, 3$, same data as allotype, CDC light trap. Córdoba: Río San Antonio (Paraje Las Jarillas, 31'32'02.8”'S, 64³3'01.7”'W, 820 m), 20', 25.XI.2007, G. Spinelli col., at light. Río Negro: meseta de Somuncura (Chipauquil), 2?, 28.II.1995, G. Spinelli col., Shannon light trap; meseta de Somuncura (estancia "El Rincón"), 20’, XI.1995, G. Spinelli col., Malaise trap.

Etymology. This species is named after Mr. Héctor "Machala" Ferreyra, technicien of the División Entomología of the Museo de La Plata, in recoginition of the valuable support given to entomologist during the past fifty years.

Discussion. This species inhabits the Patagonian steppe, and also extends its distributional range to arid zones of the northern provinces of Salta, La Rioja and Córdoba.

Dasyhelea ferreyrai is similar to the Etiopic species D. monostycta (Ingram \& Macfie, 1923), especially by the parameres shape. However, D. monostycta has banded legs, the posteromedian projection of the male sternite 9 is convex, the gonostili are shorter and the adeagus is shield-shaped. The female subgenital plate is rectangular and the neck of the spermatheca is clearly shorter.

\section{Dasyhelea grogani Díaz \& Spinelli sp. nov.} (Figs 13-24)

Diagnosis. The only Neotropical Dasyhelea with male sternite 9 stout with $\mathrm{H}$-shaped posteromedian projection and a calyx-shaped hyaline envelope, cubital fork at same level of first radial cell. Female with two ovoid spermathecae.

Male. Similar to female with usual sexual differences. Flagellum (Fig. 13). Palpus (Fig. 14) with third segment bearing scattered sensilla; PR 5.83 (5.30-6.16, $\mathrm{n}=6)$. Scutellum with 24-26 long setae, 6-8 shorter ones. Wing (Fig. 15) length $1.70(1.66-1.76, \mathrm{n}=4) \mathrm{mm}$, width 0.47 (0.44-0.50, n=5) mm, CR $0.54(0.52-0.57, n=5)$. Genitalia (Fig. 16): tergite 9 slightly tapering distally, extending to same level of apex of gonocoxite, apex truncate, apicolateral process elongate, apex sharply pointed with subapical seta; cercus very small with 2-3 setae; sternite 9 (Fig. 17) 0.6 times longer than greatest width, with $\mathrm{H}$ shaped posteromedian projection slightly notched basally, anterolateral processes of projection short, well sclerotized, posterolateral processes of projection stout, elongate, nearly straight with blunt apex; anterior, lightly sclerotized calyx-shaped hyaline envelope. Gonocoxite stout, 1.7 times longer than greatest width, with elongate, well sclerotized anteromedian process with blunt apex; gonostylus 1.2 times longer than gonocoxite, narrow at base, nearly straight, slightly curved on distal portion, tip pointed. Parameres symmetrical, apodeme slender, curved, well sclerotized, fused to posteromedian subquadrangular, poorly sclerotized process with concave apex. Aedeagus (Fig. 18) 0.45 times longer than greatest width, well sclerotized; basal arch slightly excavated; basal arms short, directed laterad; posterolateral arms slender anteriorly, ending in bulbous process with well sclerotized recurved tip directed anteromesad.

Female. Head dark brown. Eyes contiguous by width of 3-4 ommatidia. Antenna with flagellum (Fig. 19) dark brown; AR 1.07 (1.04-1.10, n=2). Clypeus (Fig. 20) with 5 pairs of setae. Palpus (Fig. 21) pale brown; third segment with 2-3 subbasal capitate sensillae, PR 4.87 $(4.83-4.91, n=2)$.

Thorax. Scutum dark brown; scutellum slightly paler, with 16 long setae, 15-16 shorter ones. Legs dark brown including tarsi, densely hairy; hind tibial comb with 5 spines; prothoracic TR 1.66 (1.61-1.72, $n=2)$, mesothoracic TR $1.80(1.75-1.85, \mathrm{n}=2)$, metathoracic TR 1.80 (1.76-1.84, n=2). Wing (Fig. 22) length $1.52 \mathrm{~mm}$, width $0.62 \mathrm{~mm}, \mathrm{CR} 0.59$; membrane hyaline, densely covered with macrotrichia; second radial cell open, well defined; cubital fork at same level of first radial cell. Halter entirely brown.

Abdomen. Dark brown. Subgenital plate (Fig. 23), anterior margin truncate, irregular, posterior margin deeply excavated; posterolateral arms stout, subtriangular. Two ovoid (Fig. 24) well sclerotized spermathecae, with short necks, measuring 0.050 by $0.038 \mathrm{~mm}$ and 0.048 by 0.034 $\mathrm{mm}$, necks $0.002 \mathrm{~mm}$.

Distribution. Argentina (Tierra del Fuego province), Chile (Deceit island).

Type material. Holotype $\overbrace{}^{\top}$, allotype + , CHILE, Magallanes Deceit island, 27.XI-03.XII.1982, D. Lanfranco col., Malaise trap. Paratypes, $60^{\circ}, 1+$ as follows: $40^{\circ}, 1+$, same data as type. ARGENTINA, Tierra del Fuego: laguna Negra (turbera, 54 50'2.1' S, 68 35'17.9' W, 15 m), 10, 04-07.XII.2008, M. Donato-G. Spinelli col., Malaise trap; laguna Negra (54²50'2.1',S, 68³5'17.9'W, 15 m), 10’, 04.XII.2008, G. Spinelli col., sweep net.

Etymology. The species is named alter our good friend Dr. William L. Grogan, from the Florida State Collection of Arthropods, Gainesville, in recognition of his superb work on ceratopogonid systematics.

Discussion. Dasyhelea grogani is similar to $D$. calvescens Macfie, 1938, a species inhabiting the Hawaiian and Wake islands, Mexico and Panama, especially by the posteromedian projection of sternite 9 and the symmetrical parameres. However, in D. calvescens the posteromedian projection of the male sternite 9 bears a distinct, slender, posteromedian process, the posterolateral arms of the aedeagus are nearly convergent and the posteromedian projection of the parameres is distinctly shorter; the female mainly differs by the divided subgenital plate and by the narrow and longer spermathecae necks. 
DíAz et al. (2010) proposed the Dasyhelea patagonica group and reviewed the seven included species, all from Argentinean and Chilean Patagonia. They also pointed out the similarities (presence of two well developed spermathecae and symmetrical parameres) and differences (ventral surface of the aedeagus covered by a hyaline envelope) with the subgenus Sebessia Remm, 1971. Although D. grogani has two well developed spermathecae and shares most of the characters with the $D$. patagonica group, it is a very hairy species and lacks the strong sclerotization around the gonopore. On the other hand, the male sternite 9 of this new species exhibits a calyx-shaped hyaline envelope, and could be assignated to the $D$. holosericea group whitin the subgenus Sebessia. Nevertheless, we prefer not to include it within Sebessia at this time, at least until specialists increase the knowledge on the immatures of the genus, which hopefully would provide new, valuable characters in order to properly propose a phylogenetic classification.
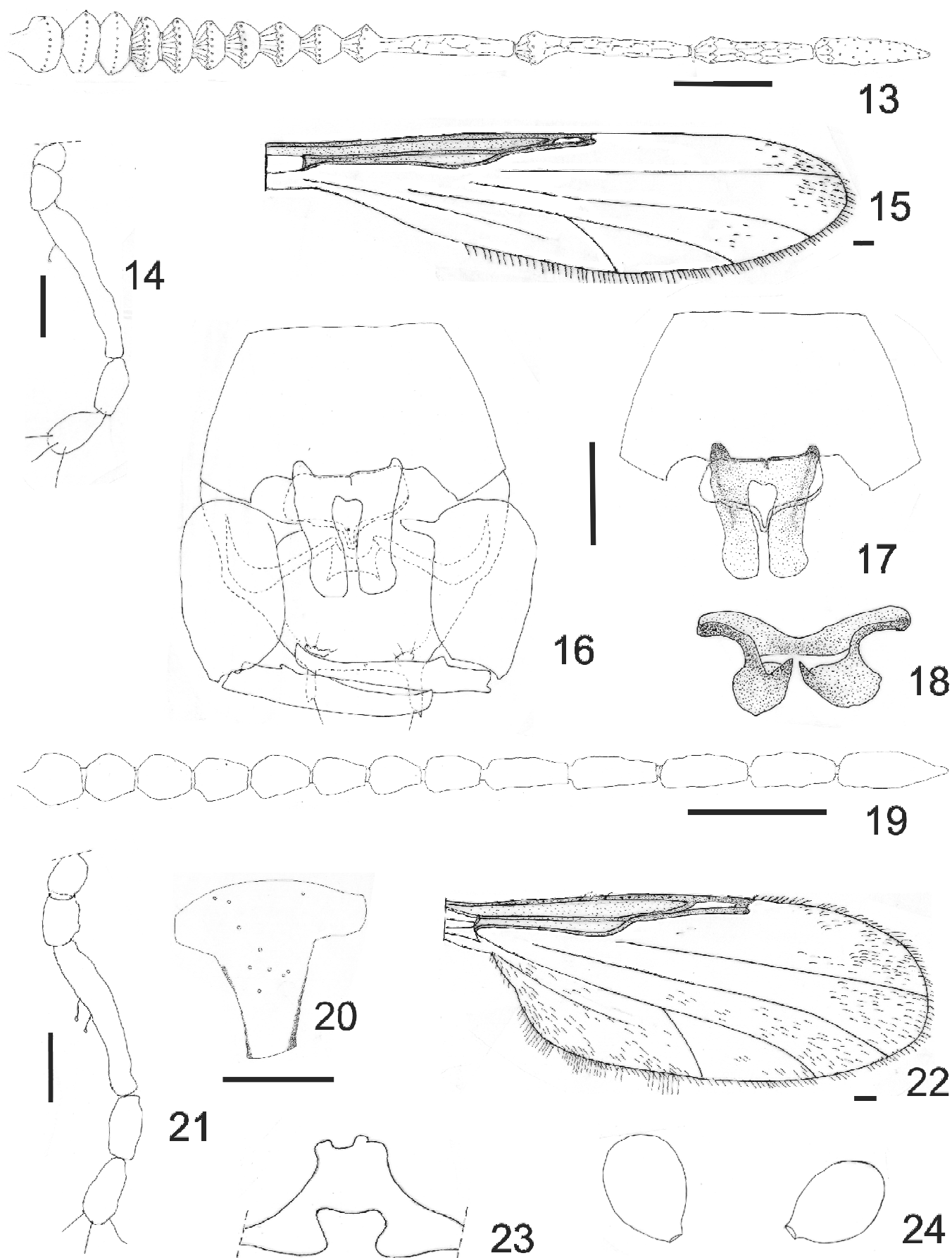

21
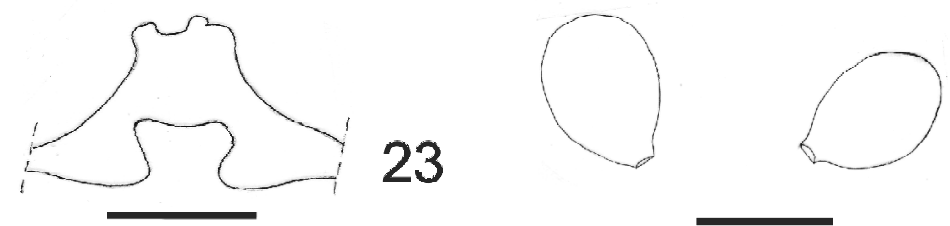

Figures 13-24. Dasyhelea grogani Díaz \& Spinelli sp. nov. 13-18, male: 13, flagellum; 14, palpus; 15, wing; 16, genitalia; 17, sternite 9; 18 , aedeagus; 19-24, female: 19, flagellum; 20, clypeus; 21 , palpus; 22, wing; 23 , subgenital plate; 24 , spermathecae. Scale bars: 0.05 mm. 


\section{Dasyhelea meloae Díaz \& Spinelli sp. nov.}

(Figs 25-31)

Diagnosis. The only Neotropical Dasyhelea with male sternite 9 conspicuous, gonocoxite with short and double curved anteromedian process and symmetrical parameres fused to small posteromedian projection, cubital fork slightly distad to end of costa. Female unknown.

Male. Head dark brown. Eyes contiguous by width of 3-4 ommatidia. Flagellum (Fig. 25); AR 0.50 (0.48-0.52, $\mathrm{n}=2$ ). Clypeus (Fig. 26) with 3 pairs of setae. Palpus (Fig. 27) brown; third segment with 1-2 subbasal capitate sensillae; PR 4.64 (4.11-5.14, $n=5)$.

Thorax. Scutum dark brown; scutellum with 7-8 long setae, 2-3 shorter ones. Legs dark brown, tarsi slightly paler; hind tibial comb with 6 spines; prothoracic TR 2.02 $(1.90-2.10, \mathrm{n}=5)$, mesothoracic TR $1.92(1.85-2.00, \mathrm{n}=5)$, metathoracic TR $1.91(1.85-2.00, \mathrm{n}=5)$. Wing (Fig. 28) length $0.85(0.84-0.90, \mathrm{n}=6) \mathrm{mm}$, width $0.32(\mathrm{n}=5) \mathrm{mm}, \mathrm{CR}$ $0.44(0.44-0.45, \mathrm{n}=6)$; membrane hyaline, densely covered with macrotrichiae; cubital fork slightly distad to level of end of costa. Halter dark brown, knob base whitish.

Genitalia (Fig. 29): tergite 9 broad distally, slightly produced beyond apex of gonocoxite, apicolateral process short, with weak apical seta; cercus with 3-4 weak setae; sternite 9 (Fig. 30) conspicuous, 0.5 times longer than greatest width, lateromedial angles well sclerotized, posteromedian excavation broad, shallow. Gonocoxite stout, 1.8 times longer than greatest width, with short, double curved, well scleortized anteromedian process, mesal inner margin with conspicuous tuft of setae; gonostylus stout, well sclerotized, 0.9 times longer than gonocoxite, nearly straight, apex truncate. Parameres (Fig. 31) symmetrical; basal arm slender, curved, fused with posteromedian projection, later small, blunt apex. Aedeagus 0.55 times longer than greatest width, anterior margin slightly convex; basal arms well sclerotized, stout at base, curved, continued to posterolateral arms, later slender, slightly convex with slightly swollen, blunt apex.

Distribution. Argentina (Río Negro and Chubut provinces).

Type material. Holotype o’, ARGENTINA, Río Negro: meseta de Somuncurá (estancia "El Rincón”), 26-30.XII.1995, G. Spinelli col. Paratypes 60', as follows: Río Negro: ruta o 33 (13 km E Clemente Onelli), 10', 04.II.1998, P. Marino col., sweep net. Chubut: meseta Sierra Cuadrada (estancia "Don Eduardo"), 50", 01, 02.XII.1996, G. Spinelli col., Malaise trap.

Etymology. This species is named after our friend and colleague Dra. Cecilia Melo, entomologist of the Instituto de Limnología “Dr. Raúl A. Ringuelet".

Discussion. Dasyhelea meloae, only known from steppe areas of Patagonia, is similar to D. pailemanensis sp. nov., sharing a very conspicuous male sternite 9 , symmetrical parameres and the inner margin of the gonocoxites bearing a tuft of strong setae. However, the legs of $D$. pailemanensis exhibit subbasal pale rings on tibiae, the distal margin of the posteromedian projection of sternite 9 is convex, and the aedeagus is bilobed with its posterolateral arms internally serrate, among other differences.

\section{Dasyhelea pabloi Díaz \& Spinelli sp. nov. \\ (Figs 32-43)}

Diagnosis. Only species of the leptobranchia group with posteromedian projection of male sternite 9 U-shaped and posterolateral arms of aedeagus subparallel with recurved tip. Female subgenital plate divided, its anterior portion elongate and posterior one subquadrangular, spermatheca rounded with straight neck.

Male. Similar to female with the usual sexual differences. Flagellum (Fig. 32). Palpus (Fig. 33) with third segment bearing scattered sensilla; PR 4.74 (4.22-5.25, $\mathrm{n}=9$ ). Scutellum with 8-10 long setae, 6-8 shorter ones. Wing (Fig. 34) length $0.91(0.84-1.00, \mathrm{n}=10) \mathrm{mm}$, width $0.30(0.28-0.34, \mathrm{n}=10) \mathrm{mm}, \mathrm{CR} 0.35(0.33-0.39, \mathrm{n}=10)$. Genitalia (Fig. 35): tergite 9 progressively tapering, rounded distally, reaching level of apex of gonocoxite, apicolateral process slender, with apical seta; cercus small, with 4 conspicuous setae; sternite 9 (Fig. 36) 0.4 times longer than greatest width, convex posteromesally, with broad, U-shaped, well sclerotized posteromedian projection. Gonocoxite stout, 1.7 times longer than greatest width; gonostylus 0.8 times longer than gonocoxite, nearly straight, tip pointed. Parameres (Fig. 37) asymmetrical, well sclerotized, apodemes slender; one basal arm stout, other slender, stout basal arm broadly fused to posteromedian projection, slender one narrowly contacting it; posteromedian projection tapering to pointed, recurved tip. Aedeagus 0.90 times longer than greatest width, anterior margin slightly excavated; basal arms slender, directed anterolaterad; posterolateral arms subparallel, nearly straight, apex recurved mesad, tip pointed.

Female. Head dark brown. Eyes contiguous by width of 3 ommatidia. Antenna with flagellum (Fig. 38) dark brown; AR 0.78 (0.69-0.85, n=6). Clypeus (Fig. 39) with 4 pairs of setae. Palpus (Fig. 40) pale brown; third segment with 2-3 subbasal capitate sensillae; PR 4.57 $(4.00-4.75, \mathrm{n}=7)$.

Thorax. Scutum dark brown; scutellum with 8-10 long setae, 4-6 shorter ones. Legs dark brown, tarsi slightly paler; hind tibial comb with 6 spines; prothoracic TR 2.06 (1.88-2.22, $\mathrm{n}=6$ ), mesothoracic TR 2.09 (2.00-2.27, $\mathrm{n}=7)$, metathoracic TR $2.01(1.84-2.36, \mathrm{n}=7)$. Wing (Fig. 41) length $0.81(0.76-0.88, \mathrm{n}=5) \mathrm{mm}$, width $0.36(0.34-0.38$, $\mathrm{n}=5) \mathrm{mm}, \mathrm{CR} 0.35(0.33-0.36, \mathrm{n}=5)$; membrane hyaline, densely covered with macrotrichiae; intercalary vein present on $\mathrm{r}_{3}$; cubital fork slightly distad to level of end of costa. Halter pale brown.

Abdomen. Pale brown. Subgenital plate (Fig. 42) divided; anterior portion, elongate, lateral margins concave, posterior margin serrate; posterior portion subquadrangular, posterolateral arms slender, curved. Spermatheca rounded (Fig. 43) well sclerotized, with straight neck; measuring 0.044 by $0.040 \mathrm{~mm}$, neck $0.006 \mathrm{~mm}$.

Distribution. Argentina (Salta, Jujuy, Neuquen, Río Negro and Chubut provinces); Chile (Malleco, Valdivia and Llanquihue provinces).

Type material. Holotype $\sigma^{\curvearrowright}$, CHILE, Llanquihue: Parque Nacional Vicente Pérez Rosales (Casa Pangue, 4102'55.0'S 71'52'31.2" W, 366 m), 18.II.2008, M. Donato col., sweep net. Allotype + , ARGENTINA, Río Negro: meseta de Somuncura 
(estancia "E1 Rincón”), 27.II.1995, G. Spinelli col., sweep net. Paratypes $510^{\prime}, 89$, as follows: $40^{\prime}, 3 \circ$ same data as allotype. Jujuy: arroyo Las Urracas (ruta 9, km 1460), 10, 23.III.2005, G. Spinelli col., sweep net. Salta: ruta 40 y río Brealito (27 km S Cachi), 10", 27.III.2005, G. Spinelli col., sweep net; 7 km SW Cafayate (río Colorado), 20', 28.III.2005, G. Spinelli col., sweep net. Neuquen: lago Aluminé, 10 19.I-02.II.1997, G. Spinelli col., Malaise trap; laguna Epulaufquen, 30', 2\%, 22.II.2001, G. Spinelli col., sweep net. Río Negro: Parque Nacional "Nahuel Huapi" (río Manso), 10, 01.II.1986, G. Spinelli col.; meseta de Somuncura (Chipauquil), 30", 27.II.1995, G. Spinelli col., sweep net; Rincón de Comi-Có (4108'35.1”S, 67027’34.6”W, 1000 m), 30’, 07.XII.2006, G. Spinelli col., Malaise trap; Paraje Chasicó (Vertiente, $41^{\circ} 08^{\prime} 28.0$ ''S, $67^{\circ} 35^{\prime} 43.9$ 'W, $\left.961 \mathrm{~m}\right), 10^{\prime}$, 06.XII.2006, G. Spinelli col., sweep net; Parque Nacional "Nahuel Huapi" (río Manso superior,

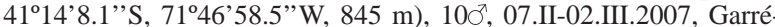
Montes de Oca col., Malaise trap; Parque Nacional "Nahuel Huapi" (río Manso medio, La Cantera, 41²1'16"S, 71²42'27.3"W, 764 m), 10, 1ㅇ, 15.I-07.II.2007, Garré-Montes de Oca col., Malaise trap; Parque Nacional Nahuel Huapi (laguna Mercedes, 4052'43.4”'S,
713' 41' 'W, 899 m), 50', 03-21.I.2008, Garre-Montes de Oca col., Malaise trap. Chubut: arroyo Las Bayas, 20', 01.XII.1999, G. Spinelli col., sweep net; Cerro Galera, 10, 02-04.XII.2002, G. Spinelli col., Malaise trap; Colonia Sarmiento (Camping "La Isla", brazo del

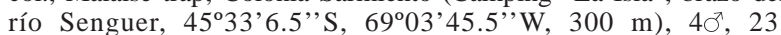
24.II.2009, G. Spinelli col., Malaise - CDC; ruta provincial $\mathrm{N}^{\circ} 12$

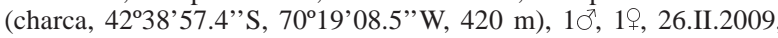
G. Spinelli col., sweep net. Santa Cruz: ruta provincial $\mathrm{N}^{\circ} 12$ (aprox. $15 \mathrm{~km}$ S Pico Truncado, 46 52,7'8.1'S, 68 05'23.5' W, $150 \mathrm{~m}$ ), $10^{7}$, 19, 23.II.2009, G. Spinelli col., sweep net. CHILE, $20^{2}$, same data as holotype. Malleco: Cord. de las Raices (40 km E Curacautin, 1650 m), 10', 05, 06.II.1979, D. M. Davis \& B. Akerbergs col.; Rio Malleco, (JAD 1702/1), 20', 21.I.1986, J. A. Downes col., sweep net (CNCI). Valdivia: Panguipulli, 10, 26.XI.1992, G. Spinelli col

Etymology. This species is named after our friend and colleague Dr. Pablo I. Marino, entomologist of the Museo de La Plata, in recognition of his valuable contributions to the taxonomy of Neotropical Ceratopogonidae.

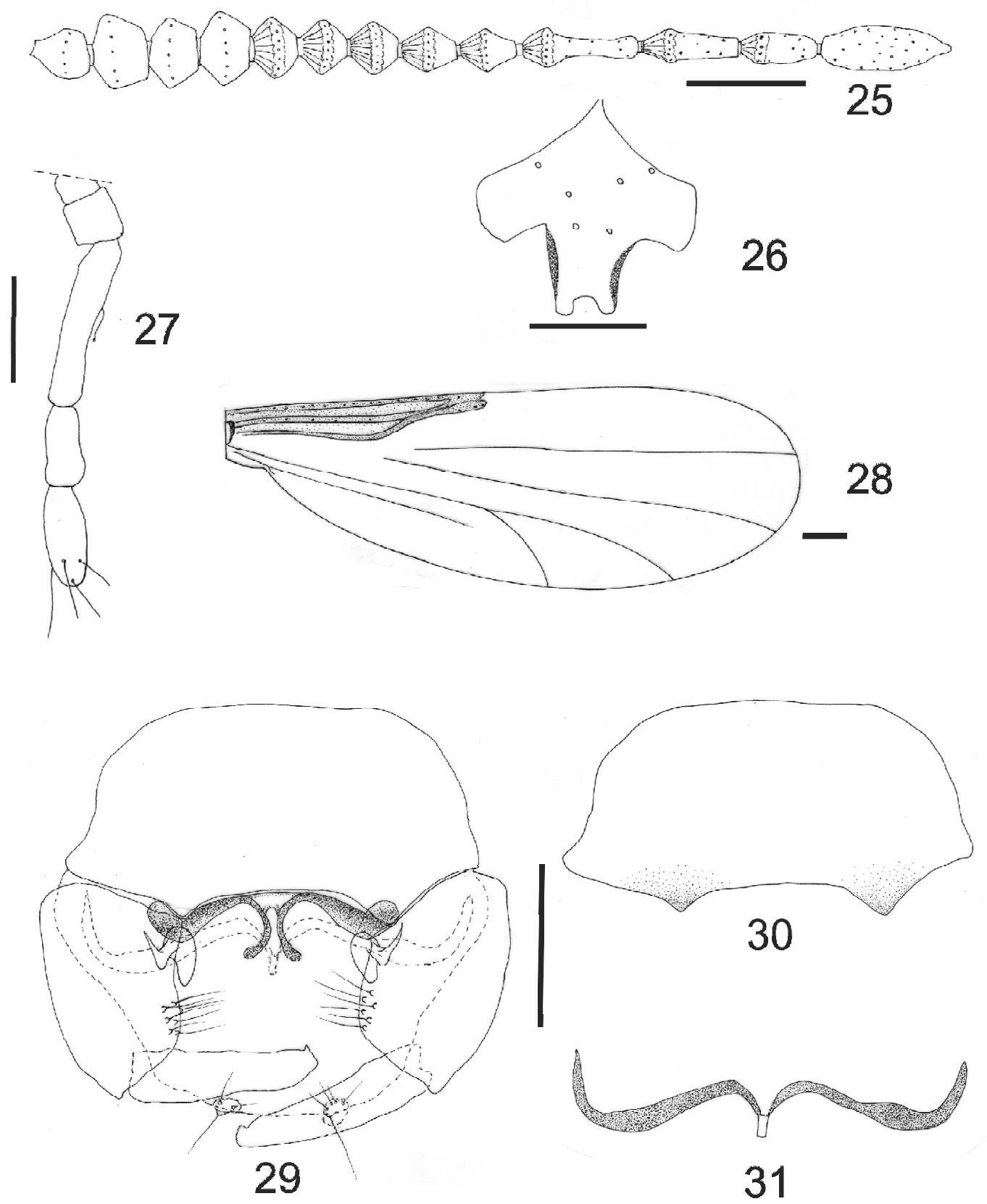

Figures 25-31. Dasyhelea meloae Díaz \& Spinelli sp. nov., male. 25, flagellum; 26, clypeus; 27, palpus; 28, wing; 29, genitalia; 30, sternite 9; 31, parameres. Scale bars: $0.05 \mathrm{~mm}$. 
Discussion. This species not only inhabits both main biomas in Patagonia, steppe and subantarctic Nothofagus forests, but also extends its distributional range to the northern provinces of Jujuy and Salta.

Dasyhelea pabloi belongs to the leptobranchia group, as diagnosed by WAUGH \& WIRTH (1976). It is very similar to the Nearctic species D. brevicosta Waugh \& Wirth, 1976 especially by the short costa, and also by the gonostili and parameres shape. However, in $D$. brevicosta the posteromedian projection of the male sternite 9 is serrate, the anterior margin of the aedeagus is straight and the posteromedian projection of parameres is clearly stouter and its recurved tip shorter; the female maily differs by the anterior portion of the subgenital plate subtriangular and by the very narrow and longer spermatheca neck. This is the first record from the Neotropical region of a species belonging to the leptobranchia group.
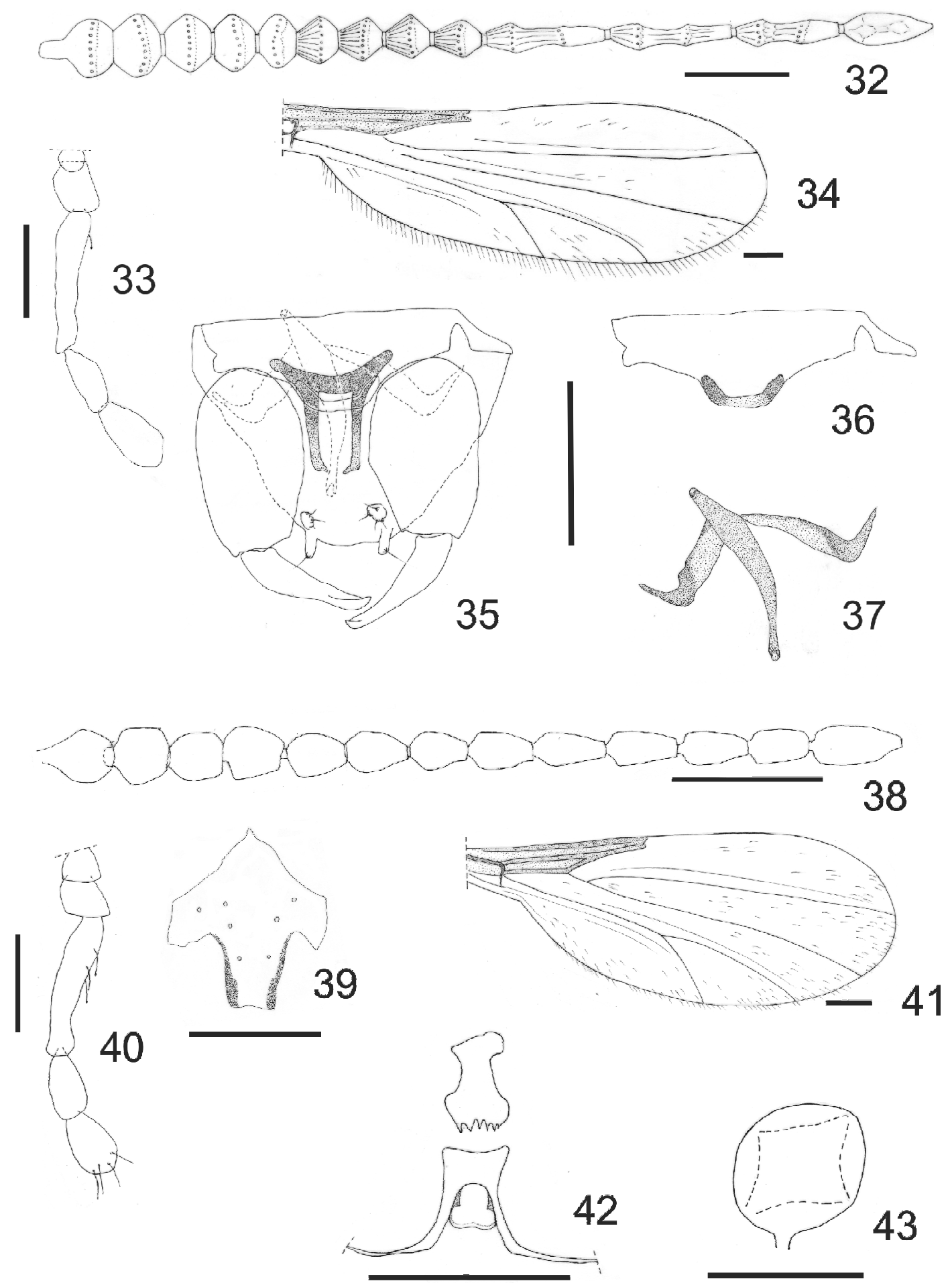

Figures 32-43. Dasyhelea pabloi Díaz \& Spinelli sp. nov. 32-37, male: 32, flagellum; 33, palpus; 34, wing; 35, genitalia; 36, sternite 9; 37, parameres; 38-43, female: 38, flagellum; 39, clypeus; 40, palpus; 41, wing; 42, subgenital plate; 43, spermathecae. Scale bars: $0.05 \mathrm{~mm}$. 
Dasyhelea pailemanensis Díaz \& Spinelli sp. nov.

(Figs 44-50)

Diagnosis. The only Neotropical Dasyhelea with male sternite 9 conspicuous, parameres symmetrical, its posteromedian projection slender with bifid tip and bilobed aedeagus with posterolateral arms curved and finaly serrate; cubital fork distad to end of costa. Female unknown.

Male. Head dark brown. Eyes contiguous by width of 3-4 ommatidia. Flagellum (Fig. 44); AR 0.46. Clypeus (Fig. 45) with 4 pairs of setae. Palpus (Fig. 46) pale brown; third segment with 2 capitate sensillae; PR 3.00.

Thorax. Scutum dark brown; scutellum with 10 long setae. Legs dark brown, tibiae with narrow, faint subbasal rings, tarsi paler; hind tibial comb with 6 spines; prothoracic TR 1.90, mesothoracic TR 2.00, metathoracic TR 1.91. Wing (Fig. 47) length $0.68 \mathrm{~mm}$, width $0.26 \mathrm{~mm}$, CR 0.41; membrane hyaline, densely covered with macrotrichiae; cubital fork distad to level of end of costa. Halter dark brown, knob base whitish.

Genitalia (Fig. 48): tergite 9 rounded distally, slightly produced beyond apex of gonocoxite, apicolateral process stout, short, with apical seta; cercus small, with 4 setae; sternite 9 (Fig. 49) conspicuous, 0.6 times longer than greatest width, surface hairy, posteromedian projection convex. Gonocoxite stout, 1.6 times longer than
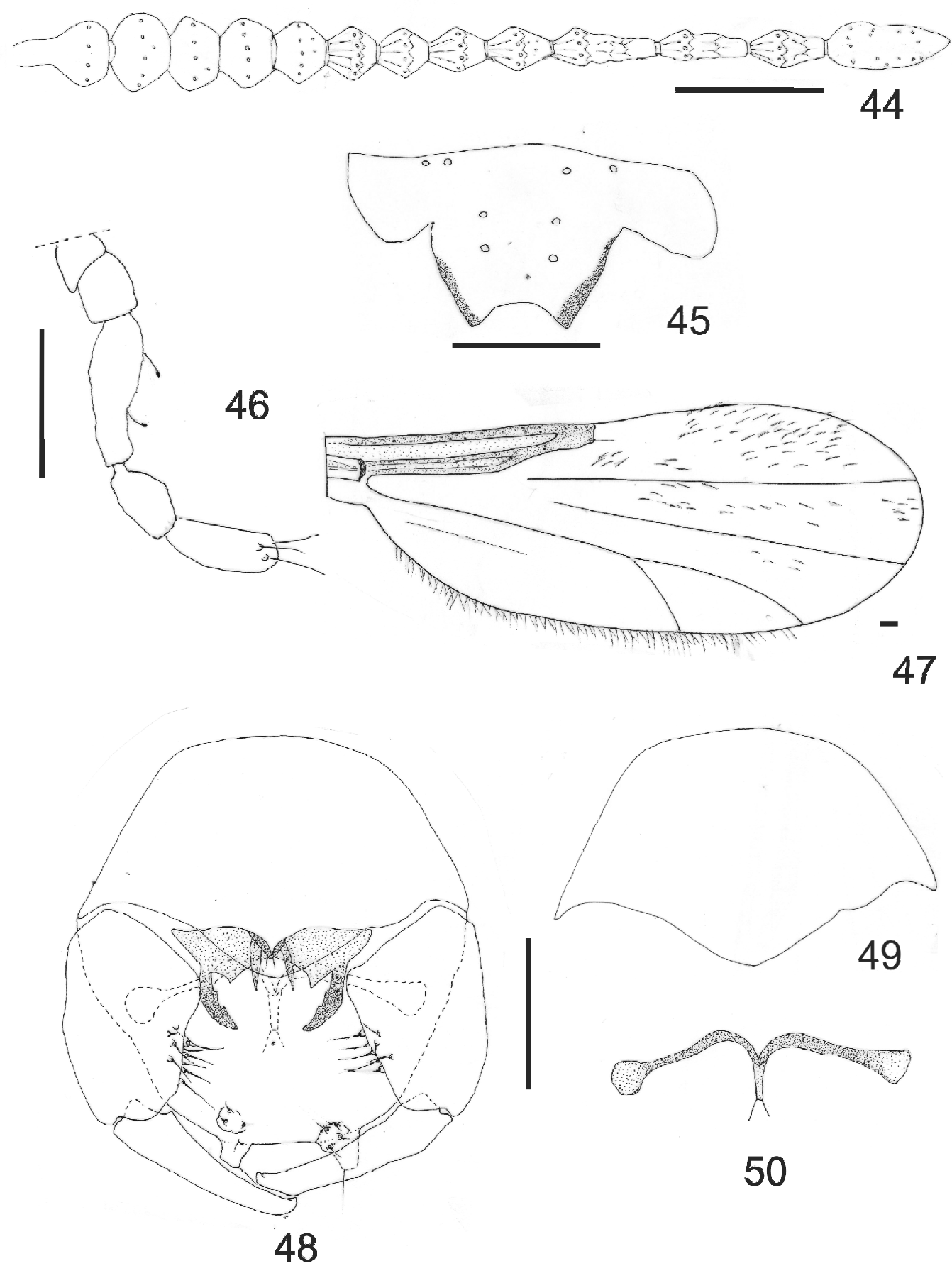

50

Figures 44-50. Dasyhelea pailemanensis Díaz \& Spinelli sp. nov., male. 44, flagellum; 45, clypeus; 46, palpus; 47, wing; 48, genitalia; 49, sternite 9; 50, parameres. Scale bars: $0.05 \mathrm{~mm}$. 
greatest width, with anteromedian process directed mesad, mesal inner margin with conspicuous tuft of setae; gonostylus 0.9 times longer than gonocoxite, nearly straight, tip pointed. Parameres (Fig. 50) symmetrical, well sclerotized; basal arm slender, slightly curved distally, fused with posteromedian projection, later slender, with bifid tip. Aedeagus 0.5 times longer than greatest width; bilobed, each lobe with body triangular, anterior margin slightly convex, tip pointed, with mesal, straight, posteriorly directed projection with pointed tip; posterolateral arm well sclerotized, curved mesad, inner margin finaly serrate, tip pointed.

Distribution. Known only from the type-locality.
Type material. Holotype ơ", ARGENTINA, Río Negro

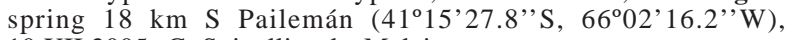
10.XII.2005, G. Spinelli col., Malaise trap.

Etymology. The name of this species refers to Pailemán, very near site from the type-locality.

Discussion. Characters for distinguishing $D$. pailemanensis from $D$. meloae may be found in the discussion under the description of the later species.

\section{Dasyhelea ricardoi Díaz \& Spinelli sp. nov.} (Figs 51-57)

Diagnosis. The only Neotropical Dasyhelea with
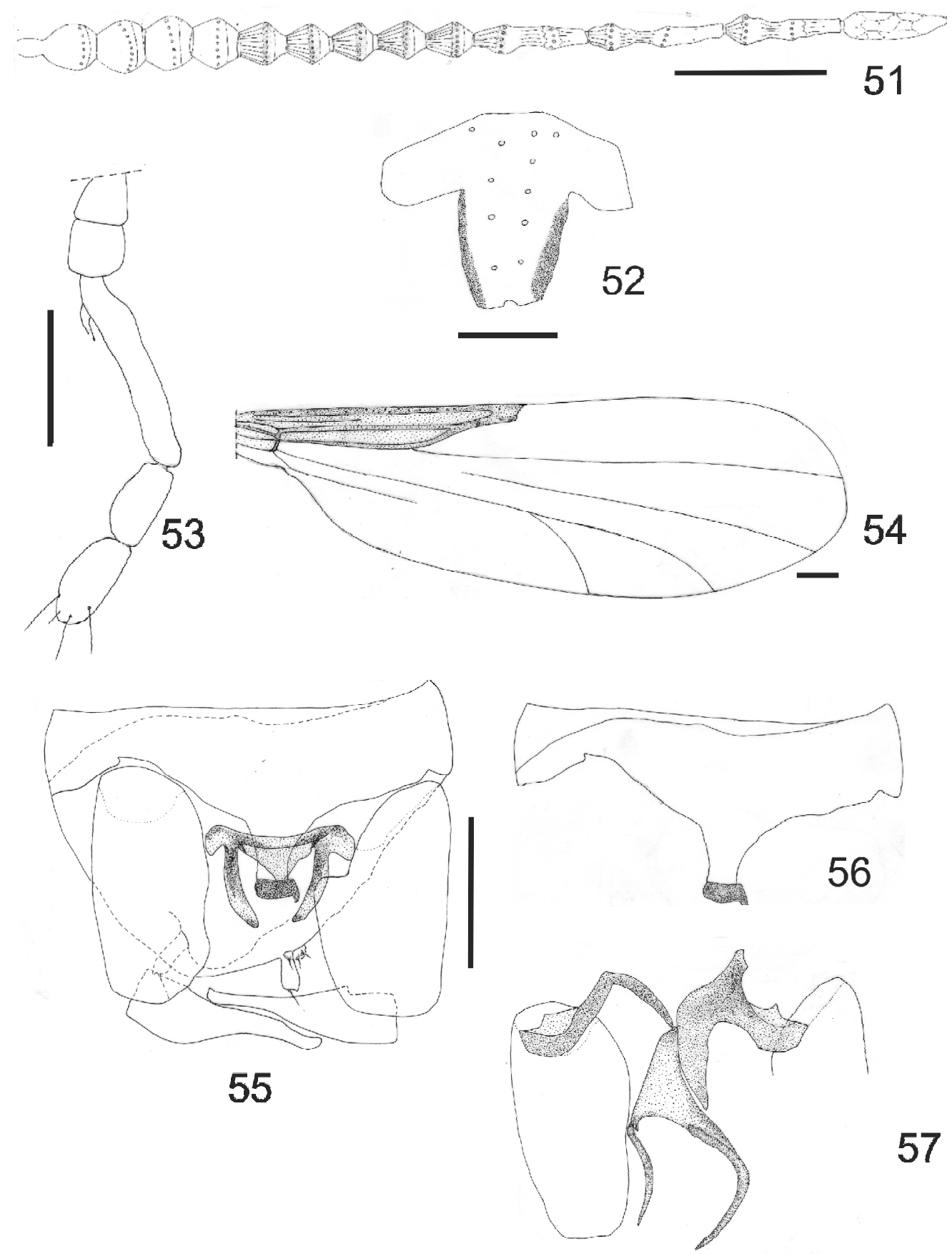

Figures 51-57. Dasyhelea ricardoi Díaz \& Spinelli sp. nov., male. 51, flagellum; 52, clypeus; 53, palpus; 54, wing; 55, genitalia; 56, sternite 9; 57, parameres. Scale bars: $0.05 \mathrm{~mm}$. 
male sternite 9 with hyaline, slender posteromedian projection and asymmetrical parameres, its posteromedian projection triangular with slender, curved projections with pointed apex, cubital fork distad to end of costa. Female unknown.

Male. Head brown. Eyes contiguous by width of 2 ommatidia. Flagellum (Fig. 51); AR 0.64 (0.62-0.68, n=3). Clypeus (Fig. 52) 6 pairs of setae. Palpus (Fig. 53) pale brown; third segment with 1-2 subbasal capitate sensillae; PR 5.06 (4.55-5.71, $\mathrm{n}=4)$.

Thorax. Scutum dark brown; scutellum with 6-8 stout setae. Legs dark brown, tarsi paler; hind tibial comb with 78 spines; prothoracic TR $1.96(1.80-2.10, n=3)$, mesothoracic TR 2.30 (2.27-2.33, n=2), metathoracic TR 2.06. Wing (Fig. 54), length $0.88(0.76-0.98, \mathrm{n}=9) \mathrm{mm}$, width $0.30(0.26-0.34$, $\mathrm{n}=9) \mathrm{mm}, \mathrm{CR} 0.42(0.41-0.45, \mathrm{n}=9)$; membrane hyaline, densely covered with macrotrichia; cubital fork distad to level of end of costa. Halter pale brown.

Genitalia (Fig. 55): tergite 9 rounded distally, not reaching level of apex of gonocoxite, apicolateral process slender, elongate, with subapical seta; cercus with 3 short setae; sternite 9 (Fig. 56) 0.3 times longer than greatest width, posterior margin convex with hyaline, slender posteromedian projection, its tip not visible. Gonocoxite stout, twice longer than greatest width; gonostylus 0.80 times longer than gonocoxite, wide base, abruptly tapering with broad apex. Parameres (Fig. 57) asymmetrical, well sclerotized; basal arms inverted U-shaped with blunt apodemes, one stout, other slender; stout basal arm widely contiguous to triangular posteromedian projection, slender basal arms narrowly contacting it; posteromedian projection well scletotized, posterolateral angles with slender, curved projections with pointed apex. Aedeagus 0.7 times longer than greatest width, anterior margin well sclerotized, nearly straight, basal arms short, laterally directed, posterolateral arms well sclerotized anteriorly, slightly curved, convergent, with pointed, well sclerotized tips.

Distribution. Argentina (Rio Negro province).

Type material. Holotype ơ, ARGENTINA, Río Negro: meseta de Somuncurá, (Chipauquil, Puesto Policial, 4057'41.1'"S, 66³8'20.8’'W, 481 m), 04.XII.2006, G. Spinelli col., sweep net.
Paratypes $80^{7}$, as follows: $10^{7}$, same data as holotype; meseta de Somuncura (estancia "El Rincón"), 60, XI.2005, G. Spinelli col., Malaise trap; Paraje Chasicó (Vertiente, $41^{\circ} 08^{\prime} 28.0^{\prime \prime} \mathrm{S}$, $\left.67^{\circ} 35^{\prime} 43.9^{\prime \prime} \mathrm{W}, 961 \mathrm{~m}\right), 10^{\circ}, 06 . X I I .2006$, G. Spinelli col., sweep net.

Etymology. The species is named in memory of the late Dr. Ricardo A. Ronderos, excellent teacher of several argentinean entomologist.

Discussion. Dasyhelea ricardoi, only known from steppe areas in the Somuncurá plateau, could be easily distinguished from other Neotropical congeners by the peculiar parameres.

\section{REFERENCES}

Borkent, A. 2009. World Species of Biting Midges (Diptera: Ceratopogonidae). Available from: http://www.inhs.illinois.edu/ research/FLYTREE/CeratopogonidaeCatalog.pdf. Accessed on: 14.06.2010.

Borkent, A. \& Forster, L. 1986. Review of the Dasyhelea fasciigera species group (Diptera: Ceratopogonidae) with a revision of the Neartic species. Canadian Journal of Zoology 64 $1280-1287$

Díaz, F.; Spinelli, G. R. \& Ronderos, M. M. 2009. Biting Midges of the Dasyhelea cincta group from Patagonia (Diptera: Ceratopogonidae). Deutsche Entomologische Zeitschrift 56(1):149-156.

Díaz, F., Spinelli, G. R. \& Ronderos, M. M. 2010. A revision of the species allied to Dasyhelea patagonica Ingram \& Macfie (Diptera: Ceratopogonidae). Journal of Natural History 44(45, 46):2825-2849

Grogan, W. L. \& Wieners, J. A. 2006. A new species of the biting midges genus Dasyhelea Kieffer (Diptera: Ceratopogonidae) from the Bahamas. Proceedings of the Entomological Society of Washington 108(2):467-473.

KiefFER, J. J. 1917. Chironomides d'Amérique conservés au Musée National Hongrois de Budapest. Annales HistoricoNaturales Musei Nationalis Hungarici 15:292-364.

McAlpine, J.; Peterson, B.; Shewell, G. E.; Teskey, H. J.; Vockeroth, J. R. \& Wood, D. M. 1981. Manual of Nearctic Diptera. Ottawa, Agriculture Canada, v. 1, Monograph 27. 674 p.

SzADZIEwsKi, R. 1996. Biting midges from Lower Cretaceus amber and Lebanon and Upper Cretaceus Siberian amber of Taimyr (Diptera: Ceratopogonidae). Studia Dipterologica 3:23-86.

Waugh, W. T. \& WirTh, W. W. 1976. A revision of the genus Dasyhelea Kieffer of the eastern United States north of Florida (Diptera: Ceratopogonidae). Annals of the Entomological Society of America 69(2):219-247.

Recebido em julho de 2010. Aceito em janeiro de 2011. ISSN 0073-4721

Artigo disponível em: www.scielo.br/isz 